\title{
Online Appendix to: \\ The Effect of Consumer Sentiment on Consumption: Cross-Sectional EVIDENCE FROM ELECTIONS
}

\author{
Christian Gillitzer \\ Nalini Prasad \\ The University of Sydney \\ UNSW Sydney
}

November 2017 
Table A1: Economic Outcomes by Political Party in Power

\begin{tabular}{|c|c|c|c|c|c|}
\hline & \multirow{2}{*}{$\begin{array}{c}\text { Mean in data } \\
\text { [standard deviation] }\end{array}$} & \multicolumn{3}{|c|}{ economic indicator $_{t}=\alpha A L P_{t}+\beta L i b / N a t_{t}+\varepsilon_{t}$} & \multirow{2}{*}{$\begin{array}{c}\alpha=\beta \\
p \text {-value }\end{array}$} \\
\hline & & ALP & Liberal/National & Difference & \\
\hline \multirow[t]{2}{*}{ GDP growth } & 3.168 & 3.247 & 3.067 & 0.180 & 0.803 \\
\hline & {$[2.859]$} & $(0.473)$ & $(0.435)$ & $(0.717)$ & \\
\hline \multirow[t]{2}{*}{ Non-farm GDP growth } & 3.235 & 3.246 & 3.222 & 0.024 & 0.970 \\
\hline & {$[2.814]$} & $(0.484)$ & $(0.366)$ & $(0.642)$ & \\
\hline \multirow[t]{2}{*}{ GDP per capita growth } & 1.810 & 1.833 & 1.780 & 0.053 & 0.943 \\
\hline & {$[2.922]$} & $(0.497)$ & $(0.455)$ & $(0.743)$ & \\
\hline \multirow[t]{2}{*}{ Employment growth (heads) } & 1.853 & 1.893 & 1.801 & 0.092 & 0.878 \\
\hline & {$[2.019]$} & $(0.476)$ & $(0.338)$ & $(0.597)$ & \\
\hline \multirow[t]{2}{*}{ Employment growth (hours) } & 1.642 & 1.797 & 1.441 & 0.356 & 0.629 \\
\hline & {$[2.972]$} & $(0.546)$ & $(0.435)$ & $(0.735)$ & \\
\hline \multirow[t]{2}{*}{ Unemployment rate } & 7.054 & 7.581 & 6.371 & 1.210 & 0.067 \\
\hline & [1.856] & $(0.567)$ & $(0.402)$ & $(0.655)$ & \\
\hline \multirow[t]{2}{*}{ Unemployment rate change } & -0.038 & -0.003 & -0.083 & 0.080 & 0.836 \\
\hline & [1.291] & $(0.277)$ & $(0.244)$ & $(0.385)$ & \\
\hline \multirow[t]{2}{*}{ Labor productivity growth } & 1.532 & 1.451 & 1.637 & -0.187 & 0.716 \\
\hline & {$[3.254]$} & $(0.358)$ & $(0.382)$ & $(0.512)$ & \\
\hline \multirow[t]{2}{*}{ TFP growth } & 0.603 & 0.338 & 0.924 & -0.586 & 0.158 \\
\hline & {$[1.094]$} & $(0.248)$ & $(0.341)$ & $(0.404)$ & \\
\hline \multirow[t]{2}{*}{ Inflation } & 3.614 & 4.233 & 2.812 & 1.421 & 0.104 \\
\hline & [3.119] & $(0.716)$ & $(0.518)$ & $(0.869)$ & \\
\hline \multirow[t]{2}{*}{ Core Inflation } & 3.759 & 4.421 & 2.903 & 1.518 & 0.036 \\
\hline & [2.181] & $(0.659)$ & $(0.344)$ & $(0.715)$ & \\
\hline
\end{tabular}

Notes: This table reports aggregate economic outcomes based on the political party in power at the national level. All economic indicators are measured on a quarterly basis from the December quarter 1982 to the December quarter 2015 - the period over which aggregate sentiment data by voting intention is available - and expressed as an annualized percentage change. The exceptions are the the unemployment rate which is measured in percentage points and the change in the unemployment rate which is expressed in annualized terms. TFP growth is measured on an annual basis and starts in 1985. The first column reports averages for each economic indicator with standard deviations in brackets. The next two columns report coefficient estimates from the regression: economic indicator ${ }_{t}=\alpha A L P_{t}+\beta L i b / N a t_{t}+\varepsilon_{t}$ where $A L P_{t}$ is a dummy variable that is equal to one if the ALP is in power and $\mathrm{Lib}_{\mathrm{N}} \mathrm{Nat}_{t}$ is a dummy variable that is equal to one if the Liberal/National Party is in power and is zero otherwise. The next column shows the difference in the coefficient estimate between ALP and Liberal/National Party governments. Newey-West standard errors using six lags (or two lags for TFP) are in parentheses. The last column shows $p$-values associated with the Wald test that $\alpha=\beta$. The first quarter of a given political party's term is assigned to the previous party in office. Standard errors in parentheses. 
Table A2: Bai and Perron (1998) Break Test Results: Major Household Item Spending Intentions: ALP minus Lib/Nat Voters

\begin{tabular}{|c|c|c|c|c|c|c|c|}
\hline \multirow{2}{*}{$\begin{array}{l}\text { UD-Max } \\
\text { test }\end{array}$} & \multirow{2}{*}{$\begin{array}{c}\text { Information } \\
\text { criteria }\end{array}$} & \multirow{2}{*}{$\begin{array}{l}\text { SupF } \\
\text { test }\end{array}$} & \multirow{2}{*}{$\begin{array}{c}\text { Sequential } \\
\text { test }\end{array}$} & \multicolumn{3}{|c|}{ Break dates (month) } & \multirow{2}{*}{$\begin{array}{l}\text { Changes of } \\
\text { government }\end{array}$} \\
\hline & & & & 3 breaks & 4 breaks & 5 breaks & \\
\hline \multicolumn{8}{|c|}{ Panel A: Unconditional spending intentions } \\
\hline \multirow[t]{9}{*}{$81.08^{* * *}$} & $\mathrm{BIC}$ & $\operatorname{SupF}(2 \mid 1)$ & 4 breaks & Feb-96 & Feb-96 & Feb-96 & Mar-96 \\
\hline & 5 breaks & $113.80^{* * *}$ & & Mar-08 & Dec-07 & Jun-00 & Nov-07 \\
\hline & LWZ & $\operatorname{SupF}(3 \mid 2)$ & & Oct-13 & Apr-10 & Dec-07 & Sep-13 \\
\hline & 4 breaks & $74.53^{* * *}$ & & & Sep-13 & Apr-10 & \\
\hline & & $\operatorname{SupF}(4 \mid 3)$ & & & & Sep-13 & \\
\hline & & $33.62^{* * *}$ & & & & & \\
\hline & & $\operatorname{SupF}(5 \mid 4)$ & & & & & \\
\hline & & 5.16 & & & & & \\
\hline & & Panel B: & nditional & ending $\mathrm{i}$ & tentions & & \\
\hline \multirow[t]{8}{*}{$86.26^{* * *}$} & $\mathrm{BIC}$ & $\operatorname{SupF}(2 \mid 1)$ & 4 breaks & Apr-96 & Apr-96 & Mar-96 & Mar-96 \\
\hline & 5 breaks & $126.90^{* * *}$ & & Dec-07 & Nov-07 & Aug-00 & Nov-07 \\
\hline & LWZ & $\operatorname{SupF}(3 \mid 2)$ & & Oct-13 & Apr-10 & Dec-01 & Sep-13 \\
\hline & 3 breaks & $59.70^{* * *}$ & & & Oct-13 & Dec-07 & \\
\hline & & $\operatorname{SupF}(4 \mid 3)$ & & & & Oct-13 & \\
\hline & & $33.92^{* * *}$ & & & & & \\
\hline & & $\operatorname{SupF}(5 \mid 4)$ & & & & & \\
\hline & & 5.18 & & & & & \\
\hline
\end{tabular}

Notes: This table reports tests for a break in the difference between the mean level of major household item spending intentions for ALP and Liberal/National voters. The UD-Max test is for an unspecified number of breaks against the null of zero breaks; the test evaluates an F-statistic for 1-5 breaks, with the breakpoints selected by global minimization of the sum of squared residuals, and each of the five F-statistics weighted equally. The LWZ statistic is a modified Schwarz criterion. The $\operatorname{SupF}(i+1 \mid i)$ test is for $i+1$ breaks against the null of $i$ breaks. The sequential test selects the number of breaks stepwise from zero breaks using the SupF test assuming a 5 percent significance level. The break dates are those identified by minimizing the sum of squared errors conditional on the number of breaks. ${ }^{* *},{ }^{* *}$ and ${ }^{*}$ represent statistical significance at the 1,5 and 10 percent levels, respectively. 
Table A3: Bai and Perron (1998) Break Test Results:

Automobile Spending Intentions: ALP minus Lib/Nat Voters

\begin{tabular}{|c|c|c|c|c|c|c|c|}
\hline \multirow{2}{*}{$\begin{array}{c}\text { UD-Max } \\
\text { test }\end{array}$} & \multirow{2}{*}{$\begin{array}{c}\text { Information } \\
\text { criteria }\end{array}$} & \multirow{2}{*}{$\begin{array}{c}\text { SupF } \\
\text { test }\end{array}$} & \multirow{2}{*}{$\begin{array}{c}\text { Sequential } \\
\text { test }\end{array}$} & \multicolumn{3}{|c|}{ Break dates (quarter) } & \multirow{2}{*}{$\begin{array}{l}\text { Changes of } \\
\text { government }\end{array}$} \\
\hline & & & & 2 breaks & 3 breaks & 4 breaks & \\
\hline \multicolumn{8}{|c|}{ Panel A: Unconditional automobile spending intentions } \\
\hline \multirow[t]{8}{*}{$52.64^{* * *}$} & $\mathrm{BIC}$ & $\operatorname{SupF}(2 \mid 1)$ & 3 breaks & Dec-95 & Dec-95 & Dec-95 & Mar-96 \\
\hline & 3 breaks & $73.03^{* * *}$ & & Jun-08 & Dec-07 & Dec-04 & Dec-07 \\
\hline & LWZ & $\operatorname{SupF}(3 \mid 2)$ & & & Jun-10 & Dec-07 & \\
\hline & 2 breaks & $15.51^{* * *}$ & & & & Jun-10 & \\
\hline & & $\operatorname{SupF}(4 \mid 3)$ & & & & & \\
\hline & & 4.54 & & & & & \\
\hline & & $\operatorname{SupF}(5 \mid 4)$ & & & & & \\
\hline & & 6.66 & & & & & \\
\hline \multicolumn{8}{|c|}{ Panel B: Conditional automobile spending intentions } \\
\hline $50.28 * * *$ & $\mathrm{BIC}$ & $\operatorname{SupF}(2 \mid 1)$ & 3 breaks & Dec-95 & Dec-95 & Dec-95 & Mar-96 \\
\hline & 3 breaks & $82.28 * * *$ & & Dec-09 & Dec-07 & Dec-04 & Dec-07 \\
\hline & LWZ & $\operatorname{SupF}(3 \mid 2)$ & & & Jun-10 & Dec-07 & \\
\hline & 2 breaks & $34.32^{* * *}$ & & & & Jun-10 & \\
\hline & & $\operatorname{SupF}(4 \mid 3)$ & & & & & \\
\hline & & 4.11 & & & & & \\
\hline & & $\operatorname{SupF}(5 \mid 4)$ & & & & & \\
\hline & & 6.62 & & & & & \\
\hline
\end{tabular}

Notes: This table reports tests for a break in the difference between the mean level of automobile spending intentions for ALP and Liberal/National voters. The automobiles spending intentions question was asked on a quarterly basis from 1995-2006, then monthly until January 2014, when it was discontinued; we use data on a quarterly basis for the whole time period. There is only 1 quarter of data following the 2013 change of government so it is not possible to test for a break at that election. See notes to Table A2 for other details. ${ }^{* * *},{ }^{* *}$ and ${ }^{*}$ represent statistical significance at the 1,5 and 10 percent levels, respectively. 
Table A4: Sentiment and Major Household Item Spending Intentions: Robustness to House Prices

\begin{tabular}{|c|c|c|c|c|c|c|c|c|}
\hline \multicolumn{9}{|c|}{ Panel A: Second stage: spend $_{i t}=\delta_{t}+\sum_{t} \sum_{j} \gamma_{j t} X_{i j t}+$ dexpect $_{i t}+\varepsilon_{i t}$} \\
\hline \multicolumn{9}{|c|}{ November 2007 election: ALP victory } \\
\hline personal: past yr & 0.515 & $(0.097)$ & & & & & & \\
\hline personal: next yr & & & 0.539 & $(0.107)$ & & & & \\
\hline economy: next yr & & & & & 0.303 & $(0.059)$ & & \\
\hline economy: 5 yrs & & & & & & & 0.330 & $(0.059)$ \\
\hline \multicolumn{9}{|c|}{ September 2013 election: Liberal/National victory } \\
\hline personal: past yr & 0.682 & $(0.085)$ & & & & & & \\
\hline personal: next yr & & & 0.681 & $(0.086)$ & & & & \\
\hline economy: next yr & & & & & 0.406 & $(0.047)$ & & \\
\hline economy: 5 yrs & & & & & & & 0.506 & $(0.061)$ \\
\hline \multicolumn{9}{|c|}{ Panel B: First stage: expect $_{i t}=\delta_{t}+\sum_{t} \sum_{j} \gamma_{j t} X_{i j t}+\lambda s u p p o r t_{i t}+\varepsilon_{i t}$} \\
\hline & persono & past yr & persona & next yr & econom? & next yr & econom & $y: 5$ yrs \\
\hline \multicolumn{9}{|c|}{ November 2007 election: ALP victory } \\
\hline support & 0.146 & $(0.012)$ & 0.139 & $(0.012)$ & 0.236 & $(0.013)$ & 0.241 & $(0.014)$ \\
\hline$R^{2}$ & 0.172 & & 0.152 & & 0.198 & & 0.107 & \\
\hline F-statistic & 138.72 & & 145.13 & & 328.95 & & 307.11 & \\
\hline Observations & 25,971 & & 24,407 & & 24,541 & & 23,616 & \\
\hline \multicolumn{9}{|c|}{ September 2013 election: Liberal/National victory } \\
\hline support & 0.199 & $(0.014)$ & 0.195 & $(0.013)$ & 0.328 & $(0.015)$ & 0.259 & $(0.014)$ \\
\hline$R^{2}$ & 0.177 & & 0.175 & & 0.157 & & 0.141 & \\
\hline F-statistic & 191.43 & & 220.83 & & 509.56 & & 336.14 & \\
\hline Observations & 25,413 & & 24,558 & & 24,886 & & 24,654 & \\
\hline
\end{tabular}

Notes: This table reports results analogous to Table 3, where the set of control variables is augmented to include changes in house prices. Specifically, $X_{i j t}$ includes the year-over-year change in house prices for the previous three years: $\triangle^{12} h p_{i t}, \triangle^{12} h p_{i t-12}$, and $\triangle^{12} h p_{i t-24}$, where $h p_{i t}$ is the log of the average level of house prices over the year to month $t$ for the statistical division in which survey respondent $i$ lives. We match survey respondents to statistical divisions using respondents' postcode of residence. The number of observations is a little smaller than for the analogous regressions in Table 3 because postcode of residence is not available for all survey respondents. House price data are available for 60 statistical divisions covering the whole country; house price data is unavailable for the period spanning the 1996 change of government. See the notes to Table 3 for other details. Robust standard errors are in parentheses. 
Table A5: Sentiment and Automobile Spending Intentions: Robustness to House Prices

\begin{tabular}{|c|c|c|c|c|c|c|c|c|}
\hline \multicolumn{9}{|c|}{ Panel A: Second stage: automobiles $s_{i t}=\delta_{t}+\sum_{t} \sum_{j} \gamma_{j t} X_{i j t}+\phi e x p e c t_{i t}+\varepsilon_{i t}$} \\
\hline \multicolumn{9}{|c|}{ November 2007 election: ALP victory } \\
\hline personal: past yr & 0.515 & $(0.101)$ & & & & & & \\
\hline personal: next yr & & & 0.550 & $(0.111)$ & & & & \\
\hline economy: next yr & & & & & 0.358 & $(0.062)$ & & \\
\hline economy: 5 yrs & & & & & & & 0.319 & $(0.061)$ \\
\hline \multicolumn{9}{|c|}{ September 2013 election: Liberal/National victory } \\
\hline personal: past yr & 0.748 & $(0.106)$ & & & & & & \\
\hline personal: next yr & & & 1.021 & $(0.161)$ & & & & \\
\hline economy: next yr & & & & & 0.489 & $(0.062)$ & & \\
\hline economy: 5 yrs & & & & & & & 0.714 & $(0.098)$ \\
\hline \multicolumn{9}{|c|}{ Panel B: First stage: expect $_{i t}=\delta_{t}+\sum_{t} \sum_{j} \gamma_{j t} X_{i j t}+\lambda$ support $_{i t}+\varepsilon_{i t}$} \\
\hline & persona & past yr & personal: & next yr & economy & : next yr & econom & $y: 5 \mathrm{yrs}$ \\
\hline \multicolumn{9}{|c|}{ November 2007 election: ALP victory } \\
\hline support & 0.151 & $(0.013)$ & 0.139 & $(0.012)$ & 0.239 & $(0.014)$ & 0.247 & $(0.015)$ \\
\hline$R^{2}$ & 0.184 & & 0.163 & & 0.207 & & 0.116 & \\
\hline F-statistic & 134.55 & & 130.93 & & 302.74 & & 290.51 & \\
\hline Observations & 23,025 & & 21,762 & & 21,955 & & 21,193 & \\
\hline \multicolumn{9}{|c|}{ September 2013 election: Liberal/National victory } \\
\hline support & 0.199 & $(0.018)$ & 0.145 & $(0.016)$ & 0.313 & $(0.018)$ & 0.212 & $(0.018)$ \\
\hline$R^{2}$ & 0.181 & & 0.158 & & 0.158 & & 0.129 & \\
\hline F-statistic & 117.96 & & 81.69 & & 291.32 & & 140.46 & \\
\hline Observations & 16,266 & & 15,682 & & 15,911 & & 15,834 & \\
\hline
\end{tabular}

Notes: This table reports results analogous to Table 4, where the set of control variables is augmented to include changes in house prices. Specifically, $X_{i j t}$ includes the year-over-year change in house prices for the previous three years: $\triangle^{12} h p_{i t}, \triangle^{12} h p_{i t-12}$, and $\triangle^{12} h p_{i t-24}$, where $h p_{i t}$ is the log of the average level of house prices over the year to month $t$ for the statistical division in which survey respondent $i$ lives. We match survey respondents to statistical divisions using respondents' postcode of residence. The number of observations is a little smaller than for the analogous regressions in Table 4 because postcode of residence is not available for all survey respondents. House price data are available for 60 statistical divisions covering the whole country; house price data is unavailable for the period spanning the 1996 change of government. See the notes to Tables 3 and 4 for other details. Robust standard errors are in parentheses. 
Table A6: ALP Vote Share Regressions

\begin{tabular}{|c|c|c|}
\hline & ALP vote share: 2007 & ALP vote share: 2013 \\
\hline Log taxable income & $\begin{array}{l}-19.22 \\
(4.68)\end{array}$ & $\begin{array}{l}-24.32 \\
(5.04)\end{array}$ \\
\hline Bachelor's degree or higher: percent & $\begin{array}{l}1.17 \\
(0.22)\end{array}$ & $\begin{array}{l}1.12 \\
(0.20)\end{array}$ \\
\hline Average age: years & $\begin{array}{l}-0.20 \\
(0.11)\end{array}$ & $\begin{array}{l}-0.24 \\
(0.12)\end{array}$ \\
\hline Unemployment rate: percent & $\begin{array}{l}1.73 \\
(0.21)\end{array}$ & $\begin{array}{l}1.05 \\
(0.25)\end{array}$ \\
\hline Share of renters: percent & $\begin{array}{l}0.00 \\
(0.05)\end{array}$ & $\begin{array}{l}-0.02 \\
(0.06)\end{array}$ \\
\hline White-collar profession: percent & $\begin{array}{l}-0.80 \\
(0.16)\end{array}$ & $\begin{array}{l}-0.74 \\
(0.19)\end{array}$ \\
\hline Industry of employment: percent & & \\
\hline Agriculture & $\begin{array}{l}-0.64 \\
(0.14)\end{array}$ & $\begin{array}{l}-0.71 \\
(0.13)\end{array}$ \\
\hline Mining \& construction & $\begin{array}{l}-0.39 \\
(0.15)\end{array}$ & $\begin{array}{l}-0.36 \\
(0.14)\end{array}$ \\
\hline Manufacturing & $\begin{array}{l}-0.16 \\
(0.13)\end{array}$ & $\begin{array}{l}0.23 \\
(0.16)\end{array}$ \\
\hline Retail \& wholesale trade & $\begin{array}{l}-0.92 \\
(0.17)\end{array}$ & $\begin{array}{l}-1.13 \\
(0.20)\end{array}$ \\
\hline Services & $\begin{array}{l}-0.39 \\
(0.19)\end{array}$ & $\begin{array}{l}-0.53 \\
(0.19)\end{array}$ \\
\hline Health and education & $\begin{array}{l}-0.60 \\
(0.16)\end{array}$ & $\begin{array}{l}-0.42 \\
(0.17)\end{array}$ \\
\hline Arts and accommodation & $\begin{array}{l}-0.75 \\
(0.25)\end{array}$ & $\begin{array}{l}-0.54 \\
(0.24)\end{array}$ \\
\hline Other & $\begin{array}{l}-1.16 \\
(0.52)\end{array}$ & $\begin{array}{l}-1.37 \\
(0.48)\end{array}$ \\
\hline Region: inner regional & $\begin{array}{l}-4.82 \\
(1.45)\end{array}$ & $\begin{array}{l}-5.02 \\
(1.56)\end{array}$ \\
\hline Region: outer regional & $\begin{array}{l}-5.16 \\
(1.77)\end{array}$ & $\begin{array}{l}-5.91 \\
(1.75)\end{array}$ \\
\hline Region: remote & $\begin{array}{l}-2.00 \\
(2.50)\end{array}$ & $\begin{array}{l}-3.36 \\
(2.50)\end{array}$ \\
\hline Region: very remote & $\begin{array}{l}1.87 \\
(3.75)\end{array}$ & $\begin{array}{l}1.15 \\
(3.87)\end{array}$ \\
\hline$R^{2}$ & 0.61 & 0.55 \\
\hline Observations & 2265 & 2264 \\
\hline
\end{tabular}

Notes: This table reports coefficient estimates from a regression of the ALP vote share on postcode-level characteristics. For the 2007 election, income is measured using 2006/07 financial year taxable income data and other variables are taken from the 2006 Census. For the 2013 election, income is measured using 2012/13 financial year taxable income data and other variables are taken from the 2011 Census. Observations are weighted by the number of voters in a postcode at each election. Baseline covariates are: home owner, blue-collar profession, public sector industry, and metropolitan location. Postcodes in the Australian Capital Territory are excluded. Standard errors in parentheses. 
Table A7: Data Sources

\begin{tabular}{|c|c|c|}
\hline Data & Source & Notes \\
\hline \multicolumn{3}{|l|}{ Individual level data } \\
\hline $\begin{array}{l}\text { Consumer sentiment } \\
\text { data }\end{array}$ & $\begin{array}{l}\text { Westpac-Melbourne Institute Survey of Consumer } \\
\text { Sentiment }\end{array}$ & $\begin{array}{l}\text { All individual level sentiment, } \\
\text { demographic and economic } \\
\text { characteristic data. }\end{array}$ \\
\hline \multicolumn{3}{|l|}{ Postcode level data } \\
\hline Census data & $\begin{array}{l}\text { ABS Census of Population and Housing } 1996 \text {, } \\
2006,2011\end{array}$ & $\begin{array}{l}\text { Education, age, } \\
\text { unemployment rate, share } \\
\text { that rent, occupation and } \\
\text { industry of work }\end{array}$ \\
\hline ALP vote share & $\begin{array}{l}\text { Australian Electoral Commission data: } 2007 \text { and } \\
2013 \text { election }\end{array}$ & $\begin{array}{l}\text { ALP two party preferred vote } \\
\text { share by polling place, which } \\
\text { is aggregated to a postcode } \\
\text { level }\end{array}$ \\
\hline Automobile purchases & $\begin{array}{l}\text { Quarterly data is from VFACTS provided by the } \\
\text { Federal Chamber of Automotive Industries. } \\
\text { Annual registration data is from the ABS Motor } \\
\text { Vehicle Census Australia (Catalogue no. 9309.0) }\end{array}$ & $\begin{array}{l}\text { Purchases by households } \\
\text { from VFACTS, total } \\
\text { registrations from ABS }\end{array}$ \\
\hline Population & $\begin{array}{l}\text { ABS Socio-Economic Index for Areas 1996, 2001, } \\
2006,2011\end{array}$ & \\
\hline Income & $\begin{array}{l}\text { Australian Taxation Office Taxation Statistics } \\
2006-07,2007-08,2008-09,2009-10,2010-11, \\
2011-12,2012-13 \\
\text { ABS Household Income and Wealth (catalogue no. } \\
6523.0 \text { ) }\end{array}$ & $\begin{array}{l}\text { Average individual taxable } \\
\text { income from the taxation } \\
\text { office and household income } \\
\text { from the ABS. }\end{array}$ \\
\hline House prices & Core Logic Australia from the SIRCA database. & $\begin{array}{l}\text { Measured at a statistical } \\
\text { division level and mapped to } \\
\text { postcodes using ABS } \\
\text { correspondences. }\end{array}$ \\
\hline Remoteness & $\begin{array}{l}\text { Australian Statistical Geography Standard: } \\
\text { Remoteness Structure }\end{array}$ & \\
\hline \multicolumn{3}{|l|}{ Other data } \\
\hline Stock market index & Bloomberg & ASX200 Index \\
\hline Political opinion polling & Newspoll published in The Australian newspaper & $\begin{array}{l}\text { Two party preferred vote } \\
\text { share }\end{array}$ \\
\hline Betting market data & Betfair & \\
\hline $\begin{array}{l}\text { GDP and non-farm } \\
\text { GDP, Employment } \\
\text { (hours), } \\
\text { Labor productivity }\end{array}$ & $\begin{array}{l}\text { ABS Australian National Accounts: National } \\
\text { Income, Expenditure and Product, Dec } 2016 \\
\text { (catalogue no. 5206.0) }\end{array}$ & \\
\hline $\begin{array}{l}\text { Employment (heads), } \\
\text { Unemployment rate }\end{array}$ & $\begin{array}{l}\text { ABS Labour Force, Australia, (catologue no. } \\
6202.0 \text { ) }\end{array}$ & \\
\hline CPI & $\begin{array}{l}\text { ABS Consumer Price Index, Australia (catologue } \\
\text { no. 6401.0) }\end{array}$ & \\
\hline Core CPI & Reserve Bank of Australia & Trimmed mean inflation \\
\hline Resident population & $\begin{array}{l}\text { ABS Australian Demographic Statistics (catologue } \\
\text { no. } 3101.0 \text { ) }\end{array}$ & \\
\hline TFP & OECD Multifactor Productivity Database & \\
\hline
\end{tabular}


Figure A1: Automobile Sales and Spending Intentions: Postcode-level Relationship

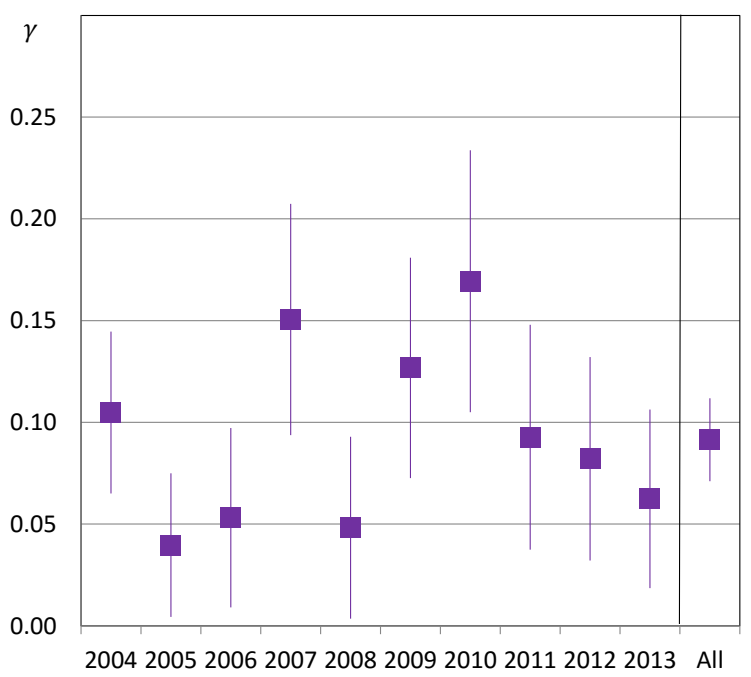

Notes: The right panel, All, shows the $\gamma$ coefficient from Equation (8); the left panel shows $\gamma_{i}$ coefficients from the analogous regression restricted to data in each year 2004-2013; the vertical bars indicate two standard error confidence bands.

Figure A2: Stock Market Returns and Postcode-level Automobile Purchases: Relationship with ALP Vote Share

(a) 2007 Election Vote Shares

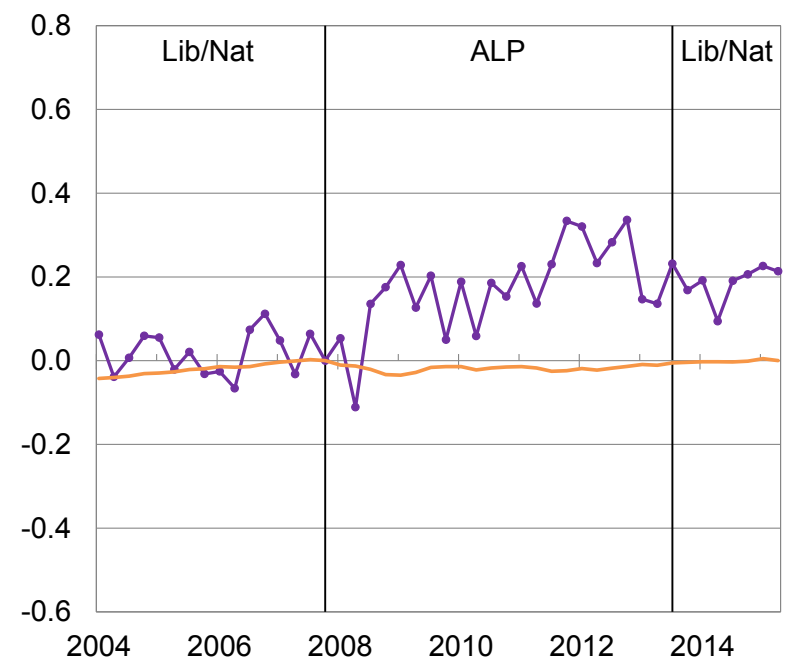

(b) 2013 Election Vote Shares

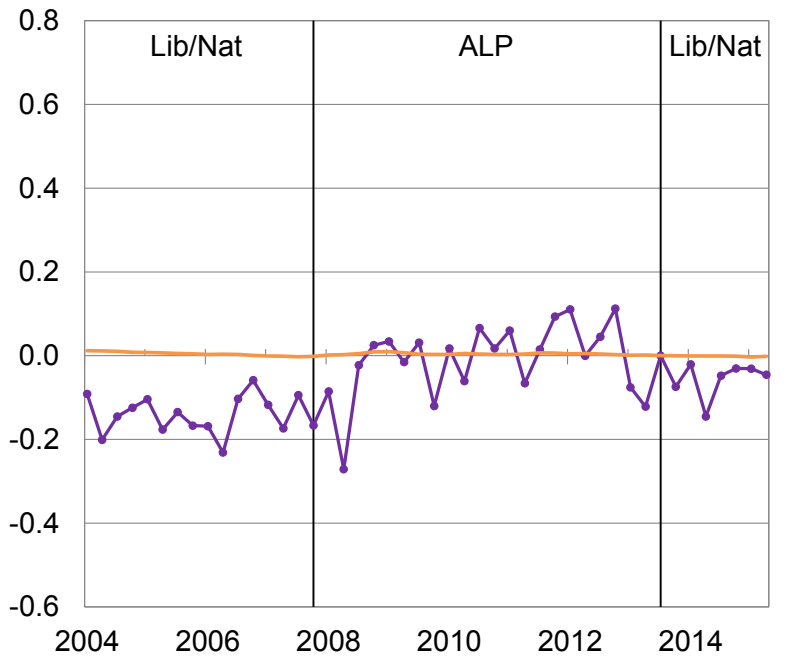

Notes: The dotted line repeats the $\beta$-coefficients shown in Figure 9 . The other lines show the fitted values from Equation (13). That is, the value of $\gamma\left(A L P_{i}^{\tau} \times \Delta^{t-T_{\tau}} \log \left(A S X_{t}\right)\right)$ for each quarter, where (a) uses $A L P$ vote shares for the 2007 election and (b) uses vote shares for the 2013 election. 
Figure A3: Components of Consumer Sentiment: Imputed Voting Intention ALP minus Liberal/National Voters

(a) Personal Finances: Current

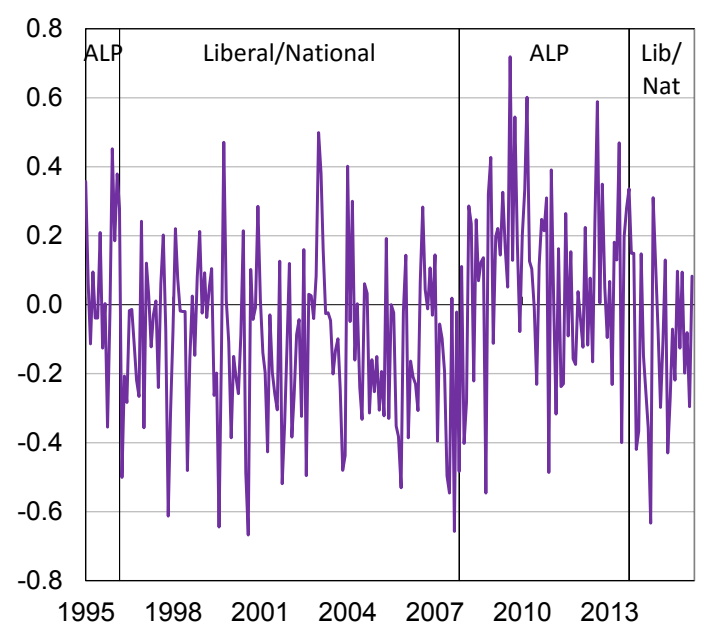

(b) Personal Finances: Next Year

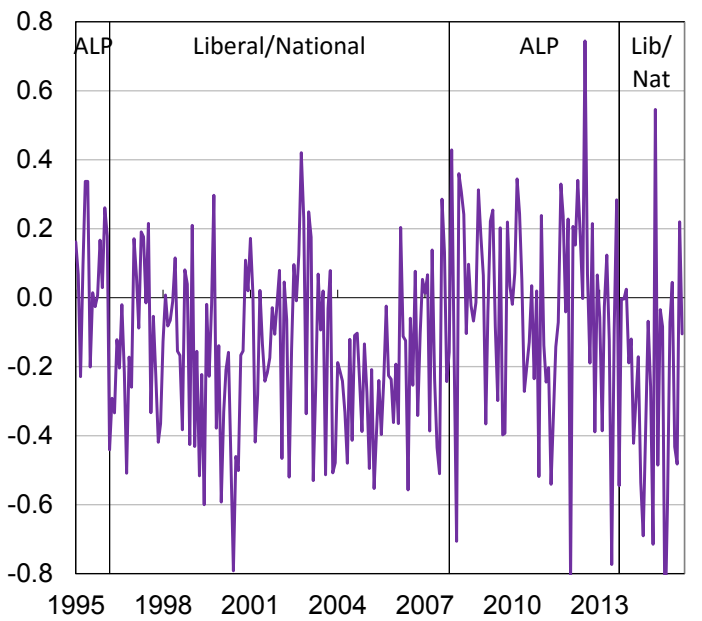

(c) Economy: Next 5 Years

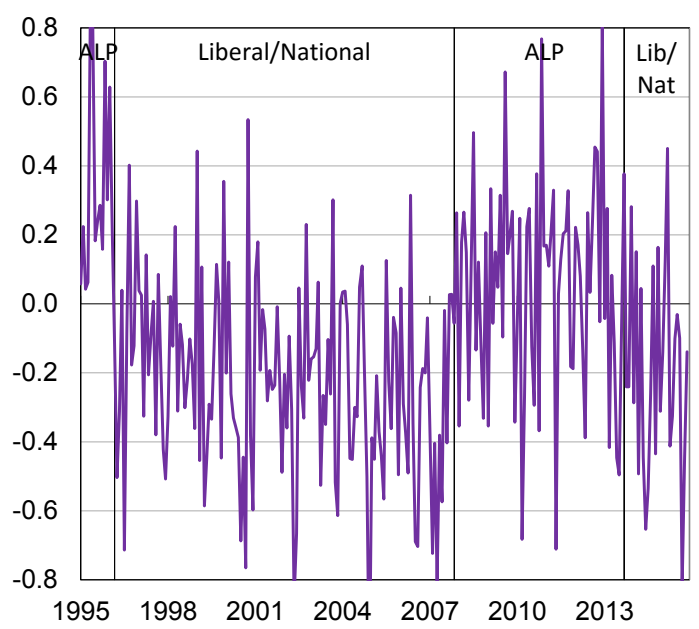

Notes: These estimates repeat those of Figures 5a, 5b and 5d using imputed rather than self-reported voting intention. Voting intention is imputed using the ALP vote share at the 2007 federal election in the postcode of residence for each survey respondent. Standard error bands are not shown for clarity. See notes to Figures 5 and 13 for further details. 


\section{Figure A4: Voting Intention and Automobile Purchases: By Total Registration and Purchases By Households}

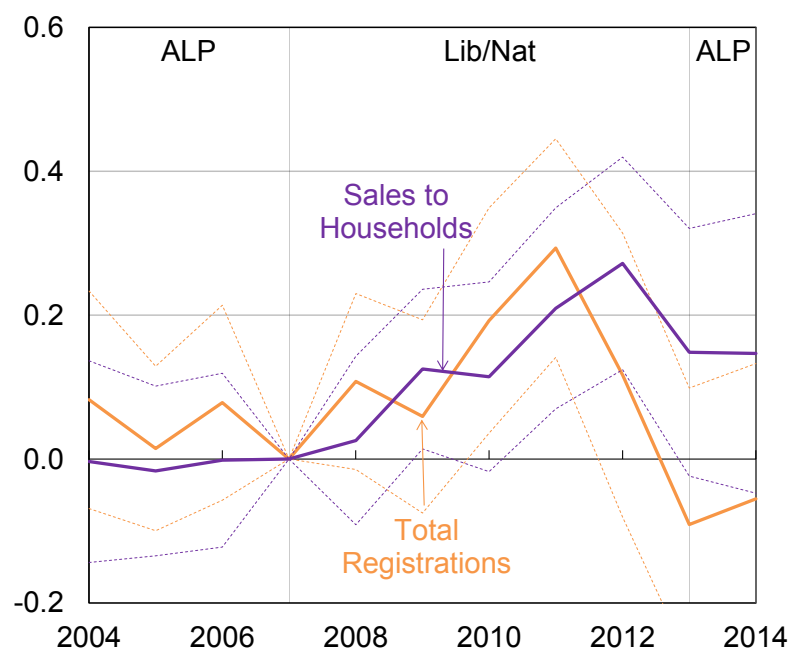

Notes: The graph shows the estimated coefficients $\beta_{j}$ for Equation (9) together with two standard error confidence bands, using annual vehicles data and 2007 vote share data; the coefficients $\beta_{j}$ are relative to the omitted year 2007, when the ALP won government. We measure per capita automobile purchases in two ways: purchases by households and registration data that includes purchases by households, businesses and the government; registration data are available only at an annual frequency. 


\section{References}

Bai, Jushan, and Pierre Perron. 1998. "Estimating and Testing Linear Models with Multiple Structural Changes." Econometrica, 66(1): 47-78. 